\title{
Effect of ACE inhibitors on Creatinine Clearance and albuminuria in diabetic nephropathy
}

\author{
Mona Hosny Abdel-Salam \\ Internal Medicine Department \\ Ain Shams University
}

\begin{abstract}
:
30 diabetic female patients were studied for the effect of Ramipril on creatinine clearance and albuminuria, they all were type 2 diabetes mellitus and were on oral hypoglycemic drugs. They all had variable degrees of hypertenison. Ramipril was taken for 3 months in a variable doses between 5 and $10 \mathrm{mg} /$ day. Creatinine clearance and albuminuria were determined before and after treatment. Patients were divided into 3 groups:

Group 1: 10 patients with albuminuria and mild hypertension.

Group 2: 10 patients with albuminuria and moderate hypertension.

Group 3: 10 patients with macroalbuminuria and moderate to severe hypertension.

In our study, Group 1 has made maximum benefit of Ramipril as regards highly significant decrease $(\mathrm{P}=.002)$ of creatinine clearance and of albuminuria which improved significantly $(\mathrm{P}=.001)$.

Group 2 had a lesser success with only decrease of albuminuria significantly $(\mathrm{P}=.005)$ but with insignificant decrease of level of creatinine clearance.

Group 3 with macroalbuminuria did not benefit from Ramipril effect on albuminuria but there was a significant decrease in creatinine clearance below normal levels $(\mathrm{P}=.001)$.

Conclusion: Early and tight control of blood pressure by Ramipril is needed to achieve a success in treating diabetic nephropathy with microalbuminuria. In our study, patients with macroalbuminuria did not benefit from Ramipril treatment.
\end{abstract}

\section{Introduction}

It has now become obvious that type 2 diabetes must be taken every bit as seriously as type 1 diabetes, in part because of its renal complications. Moreover, some recent and encouraging evidence indicates that diabetic nephropathy and deterioration of renal function are to a certain extent preventable (Ritz et al., 1999).

In diabetic nephropathy, angiot ensin - converting - enzyme (ACE) inhibitors have a greater effect than other antihypertensive drugs on prot einuria and the progressive decline in glomerular filtration rate (GFR). ACE inhibitors have beneficial effects on the permeability and size-selective function of the glomerulus; these effects would lead to limited ultrafiltration of macromolecules and proteins (Ruggenenti et al., 1997).

Ramipril Efficacy in nephro pathy (REIN) study found that in patients with chronic nephropathies and proteinuria, ramipril safely reduced the rate of decline of the glomerular filtration rate (GFR) and halved the risk of doubling of serum creatinine or end- 
stage renal failure (ESRF) (Ruggenenti et al., 1998).

In the study of the Heart Outcomes Prevention Evaluation (HOPE) Study Investigators, Ramipril lowered the risk of overt nephropathy by $24 \%$ (Stubanus et al., 2000).

\section{Patients and Methods}

30 patients with diabetes mellitus of various durations were chosen from Nephrology department, Ain Shams University Hospital. They all had albuminuria and hypertension of variable degrees.

\section{They were divided into 3 groups:}

1. Group 1: comprised 10 patients with albuminuria $(<300 \mathrm{mg} /$ day $)$ and mild hypertension.

2. Group 2: comprised 10 patients with albuminuria $(<300 \mathrm{mg} /$ day $)$ and moderate hypertension.

3. Group 3: comprised 10 patients with macroalbuminuria (>300mg/day) and hypertension ranging between moderate and severe grades.

For all patients, the following was done:

1. Complete history and clinical examination including age, duration of diabetes mellitus, hypertension degree and lower limb Oedema grades.

2. Abdominal Sonography .

3. Blood chemistry including urea and creatinine.

4. Creatinine clearance and albumin in urine, which were determined before Ramipril treatment and after 3 months of continuous Ramipril treatment.

5. The dose of Rampiril taken was as follows:

Group 1: a dose of $5 \mathrm{mg} /$ day
- Group 2 and Group 3: a varying dose of 5 to $10 \mathrm{mg} /$ day according to the case.

All 30 patients were on oral hypoglycemic drugs and were type 2 diabetes mellitus.

Creatinine clearance was

determined by collecting 24 hours urine and determining urinary and serum creatinine, then using the equation $\frac{\mu \mathrm{x} V}{\mathrm{P}}$ Albumin in urine was determined by radioimunoassay.

\section{Results}

Age and Duration: Statistical Comparison of different groups was made in tables (1), (2) and (3)

\section{Hypertension (HTN)}

- Mild Hypertension up to 139/104.

- Moderate Hypertension up to 199/114.

- Severe Hypertensionup to 200/ 115.

1. In group 1, $100 \%$ of patients had mild hypertension.

2. In group 2, $100 \%$ of patients had moderate hypertension.

3. In group 3, 20\% had severe hypertension while $80 \%$ had moderate hypertension.

\section{Lower limb oedema:}

Mild oedema $\longrightarrow$ ankle level moderate oedema $\longrightarrow$ Knee level Severe oedema $\longrightarrow$ generalized (including face)

There was a highly significant presence of lower limbs oedema $(\mathrm{P}=.0001)$ in different groups, being:

1. In group 1:70\% had mild oedema and $30 \%$ had no oedema.

2. In group 2 : $100 \%$ had moderate oedema. 
3. In group 3:80\% had moderate oedema and $20 \%$ had Severe oedema.

\section{Grades of nephropathy in} ultrasound:

1. Grade 1: Mild increase in cortex echogenecity but less than that of liver or spleen, together with corticomedullary differentiation.

2. Grade 2: Mild increase in cotex echogenecity equal to that of Liver or Spleen, but Still there is cortico -medullary differentiation.

3. Grade 3: Loss of Corticomed -ullary differentiation with increased echogenecity.

There was a highly Significant $(\mathrm{P}=$ $.001)$ presence of nephropathy of various grades in the three groups.
In group $1: 70 \%$ had grade 1 nephropathy and $30 \%$ had grade 2 nephropathy.

In group 2: $80 \%$ had grade 2 nephr opathy and $20 \%$ had grade 1 nephropathy.

In group $3: 70 \%$ had grade 2 nephropathy and $30 \%$ had grade 3 nephropathy.

$\underline{\text { Urea }}$ Creatinine, Creatinine Clearance before Ramipril, Creatinine Clearance $\underline{\text { after Ramipril, Albumin in urine before }}$ Ramipril and Albumin in urine after Ramipril: Statistical comparison between results of various groups are present in table (1), (2) and (3).

Table (1) Statistical Comparison between Group (1) and Group (2) results.

\begin{tabular}{|l|l|l|l|}
\hline $\begin{array}{l}\text { Vareints } \\
\text { Age (years) }\end{array}$ & $\begin{array}{l}\text { Groupt (1) } \\
49.40 \pm 2.91\end{array}$ & $\begin{array}{l}\text { Group (2) } \\
52.40 \pm 2.91 \\
\text { Duration of DM (years) }\end{array}$ & $\begin{array}{l}\text { Pvalue } \\
\text { N.S. }\end{array}$ \\
$\begin{array}{l}\text { Urea (mgldl) } \\
\text { Creatinine (mg) }\end{array}$ & $40.50 \pm 2.01$ & $48.40 \pm 10.67$ & .000 Sig \\
$\begin{array}{l}\text { Creat Clearance before Ramipril } \\
\text { (ml/md) }\end{array}$ & $101.10 \pm 9.0$ & $90.31 \pm 5.35$ & N.S. \\
$\begin{array}{l}\text { Create, Clearance after Ramipril } \\
\text { (ml/mm) }\end{array}$ & $94.10 \pm 7.88$ & $85.80 \pm 7.71$ & N.S. \\
$\begin{array}{l}\text { Albumin in urine before Rampiril } \\
\text { (mg/day) }\end{array}$ & $259.50 \pm 36.32$ & $270.50 \pm 38.32$ & N.S. \\
$\begin{array}{l}\text { Albumin in urine after Ramipril } \\
\text { (mg/day) }\end{array}$ & $234.60 \pm 43.92$ & $293.00 \pm 44.73$ & N.S. \\
\hline
\end{tabular}


Table (2) Statistical Comparison between Group (1) and Group (3)

\begin{tabular}{|l|l|l|l|}
\hline Vareints & Groupt (1) & Group (3) & Pvalue \\
Age (years) & $49.40 \pm 2.91$ & $50.50 \pm 4.8$ & N.S. \\
Duration of DM (years) & $9.50 \pm 2.01$ & $17.90 \pm 2.4$ & $.0000 \mathrm{Sig}$ \\
$\begin{array}{l}\text { Creatinine (mg) } \\
\begin{array}{l}\text { Creat Clearance before Ramipril } \\
\text { (ml/mn) }\end{array}\end{array}$ & $101.10 \pm 9.0$ & $86.30 \pm 10.97$ & $.0000 \mathrm{Sig}$ \\
$\begin{array}{l}\text { Create, Clearance after Ramipril } \\
\text { (ml/mn) }\end{array}$ & $94.10 \pm 7.88$ & $1.73 \pm .39$ & $.0000 \mathrm{Sig}$ \\
$\begin{array}{l}\text { Albumin in urine before Ramipril } \\
\text { (mg/day) }\end{array}$ & $259.50 \pm 36.32$ & $3930 \pm 2020$ & $.0000 \mathrm{Sig}$ \\
$\begin{array}{l}\text { Albumin in urine after Ramipril } \\
\text { (mg/day) }\end{array}$ & $234.60 \pm 43.92$ & $3770 \pm 1534.81$ & $.0000 \mathrm{Sig}$ \\
\hline
\end{tabular}

Table (3) Statistical Comparison between Group (2) and Group (3)

\begin{tabular}{|l|l|l|l|}
\hline Vareints & Groupt (2) & Group (3) & Pvalue \\
Age (years) & $52.40 \pm 2.91$ & $50.50 \pm 4.8$ & N.S. \\
Duration of DM (years) & $13.40 \pm 1.83$ & $17.90 \pm 2.4$ & .0000 Sig \\
Urea (mg/dl) & $48.40 \pm 19.2$ & $86.30 \pm 10.97$ & .0000 Sig \\
Creatinine (mg) & $.81 \pm .32$ & $1.73 \pm .39$ & .0000 Sig \\
$\begin{array}{l}\text { Creat Clearance before Ramipril } \\
\text { (ml/mn) }\end{array}$ & $90.30 \pm 5.35$ & $73.2 \pm 12.9$ & .0000 Sig \\
$\begin{array}{l}\text { Create, Clearance after Ramipril } \\
\text { (ml/mn) }\end{array}$ & $85.80 \pm 7.71$ & $58.60 \pm 14.00$ & $.0000 \mathrm{Sig}$ \\
$\begin{array}{l}\text { Albumin in urine before Ramipril } \\
\text { (mg/day) }\end{array}$ & $270.50 \pm 38.32$ & $3930 \pm 2020$ & $.0000 \mathrm{Sig}$ \\
$\begin{array}{l}\text { Albumin in urine after Ramipril } \\
\text { (mg/day) }\end{array}$ & $293.00 \pm 44.73$ & $3770 \pm 1534.81$ & $.0000 \mathrm{Sig}$ \\
\hline
\end{tabular}


Table (4) Statistical comparison between creatinine clearance before and after Ramipril treatment in every group

\begin{tabular}{|l|ll|}
\hline Group & 2-tail Sig & \\
\hline Group 1 & .002 & Highly significant \\
\hline Group 2 & 0.120 & NS \\
\hline Group 3 & .001 & Highly significant \\
\hline
\end{tabular}

Table (5)

Statistical comparison between Albuminuria before and after Ramipril treatment in each group

\begin{tabular}{|l|ll|}
\hline Group & 2-tail Sig & \\
\hline Group 1 & .001 & Highly significant \\
\hline Group 2 & .005 & Highly significant \\
\hline Group 3 & .632 & NS \\
\hline
\end{tabular}

From table 4 and 5:

Group 1 has made significant difference as regards both creatinine clearance and albumin in urine before and after Rampiril treatment.

Group 2 did not show significant change as regards creatinine clearance following Ramipril treatment, but there was significant decerase in albuminuria level.

Group 3 did not show change in albuminuria level following Ramipril therapy but there was a significant change in creatinine clearance showing a decrease in GFR.

\section{Discussion}

The Ramipril Efficacy in Nephropathy (REIN) study found that in patients with chronic nephropathies and proteinuria of $3 \mathrm{gm}$ or more per 24 hours, Ramipril safely reduced the rate of decline of Glomerular filtration rate (Ruggenenti et al., 1998).

In our study, patients with albuminuria and mild hypertension, Ramipril has lowered the creatinine clearance, highly significant decrease $(=.002)$ has occured. Patients with albuminuria and moderate hypertension didn't show the same decrease may be because of high prevalence of grade 2 nephropathy among this group.

Patients with macroalluminuria and moderate to severe hypertension showed a highly significant decrease in creatinine clearance below normal, which would incriminate Ramipril use in this group of patients.

The results obtained as regards creatinine clearance in groups 1 and 2 is going well with the HOPE study (Stubanus et al., 2000) but the group 3 with macroalluminuria and moderate to severe hypertension did not show improvement as regards creatinine clearance or albuminuria. Decline in creatinine clearance in this group may be due to initial lowering of GFR suggested to be done by ACE inhibitors during the first 6 weeks of use.

In the results of HOPE study and MICRO-HOPE study, (Grestein et al., 2000), Ramipril lowered the risk of overt nephropathy. In our study, group (1) and (2) with albuminuria and mild to moderate hypertension have made benefit from Rampiril while the third 
group with macroalbumuria did not benefit.

In (Ruggenenti et al., 2000) study showed that nephropathy progression was remarkably faster in patients with type 2 diabetes mellitus than in other patients with primary glomerular disease.

This was only applicable to group 3, there was a significant decrease $(\mathrm{P}=.001)$ in creatinine clearance below normal, which did not apply to group 1 and 2, may be because of the structural changes that accompany macroalbuminuria.

\section{Conclusion}

Patients with type $2 \mathrm{DM}$ has to start treatment as early as possible with Ramipril, especially so when microalbuminuria or hypertension is detected.

\section{References}

1. Gerstein H.C.; Yusuf S.; Mann JFE.; Moogwerf B.; Zinman B.; Held C., Fisher M.; Wolffenbuttel B.; Bosch J. and Malle J-P.: Effects of Ramipril on Cardiovascular and microvascular outcomes in people with diabetes mellitus: Results of the HOPE Study and MICRO-HOPE Substudy. The Lancet 2000, Vol 355, Jan 22: 253 259.

2. Ritz E. and Ranhold S.: Nephropathy in patients with type 2
DM. New England J. of Medicine 1999; vol 341; Number 15: $1127-$ 1133.

3. Ruggenenti P.; Perna A.; Mosconi L.; Matalone M.; Garini G.; Salvadori M.; Zoccali C.; Scolari F.; Maggiore Q.; Tognoni G. and Remuzzi G.: Randamised Placebo-controlled trial of effect of Ramipril on decline in Glomerular filtration rate and risk of terminal renal failure in proteinuric, nondiabetic nephropathy. The Lancet 1997; June 28; vol 349: 1857-1863.

4. Ruggenenti P.; Perna A.; Gherardi G.; Gaspari F.; Benini R. and Remuzzi G.: Renal fucntion and requirement for dialysis in chronic nephropathy patients on long-term Ramipril: REIN follow-up trial. The Lancet; 1998; Vol 352; October 17: 1252-1256.

5. Ruggenenti P.; Annalisa P.; Stat-Sci D., Gherardi G.; Benini R. and Remuzzi g.: Chronic proteinuric Nephropathies: Outcome and response to treatment in a prospective cohort of 352 patients with different patterns of renal injury. American Journal of Kidney diseases 2000; Vol 35; No. 6 (June): 1155-1165.

6. Stubanus M.; Endemann D.; Fischereder M.; Ittner K.P. and Kramer B.K.: the Lancet 2000 Apr. 1; 355 (9210): 1183, discussion $(1183=1184)$. 


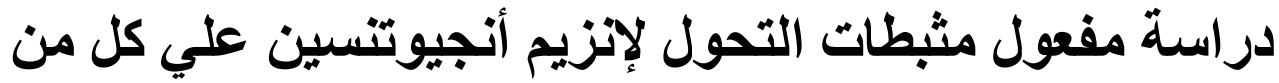

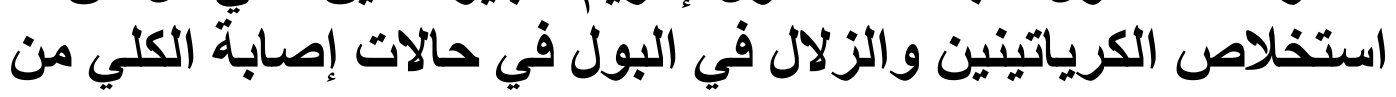 مرض البول السكري مني حسني عبد السلام البول

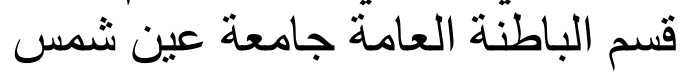

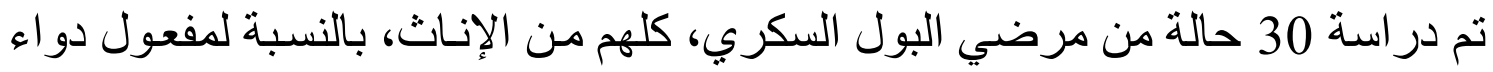

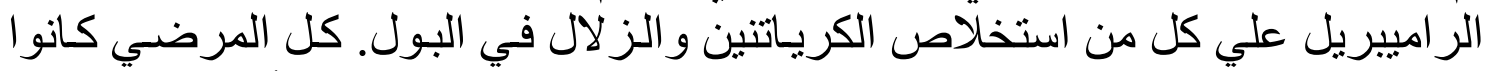

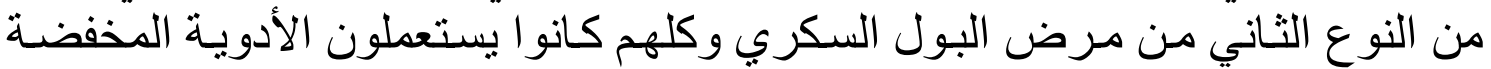

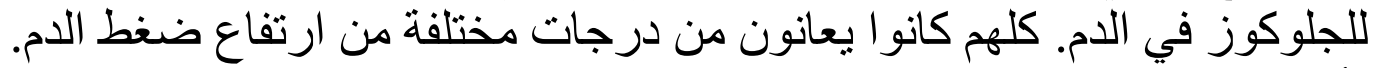

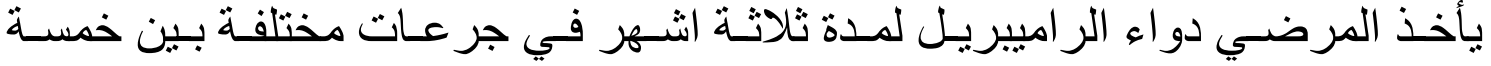

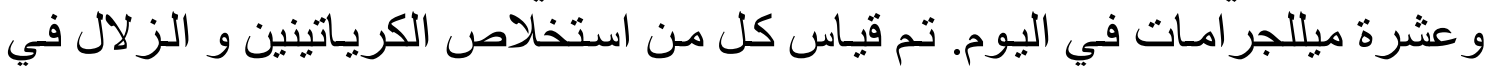
البول قبل وبعد العلاج.

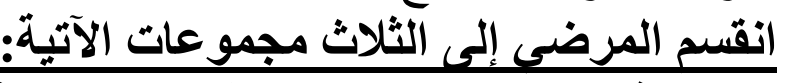

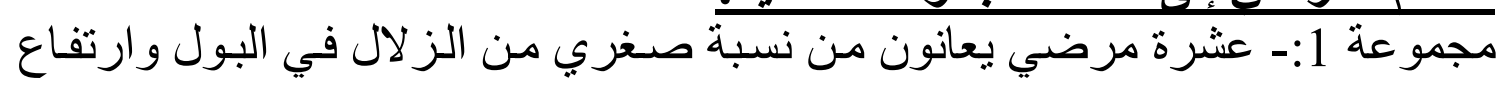

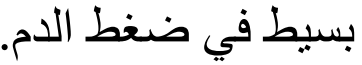
مجمو عةٌ 2: - عشرة مرضي يعانون من نسبة صغري من الز لال في البول وارتفاع

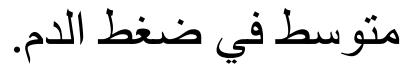

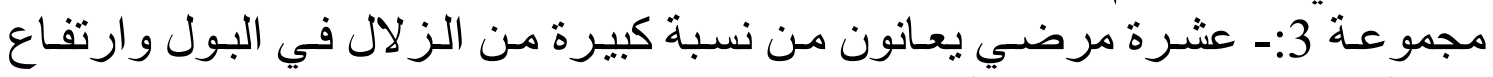

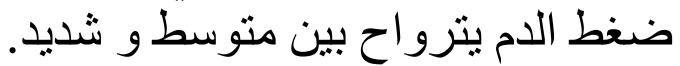

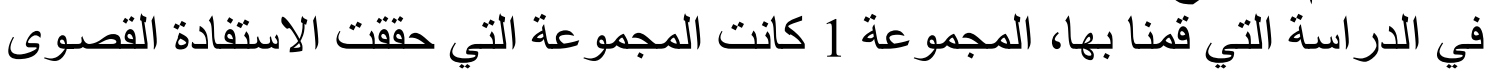

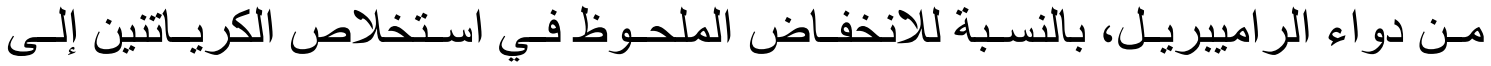

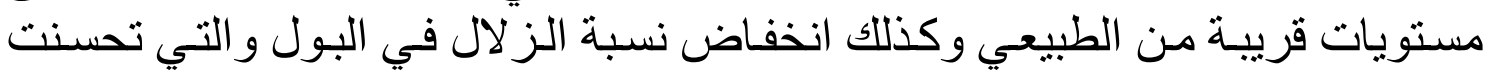

بصورة ملحوظة. المجموعة الثانية حققت نجاحا اقل مع انخفاض ملحوظ في نسبة زلال البول البول فقط، أمـا استخلاص الكرياتتين فلم يحقق انخفاض ملحوظ من المستويات التهات الطبيعية.

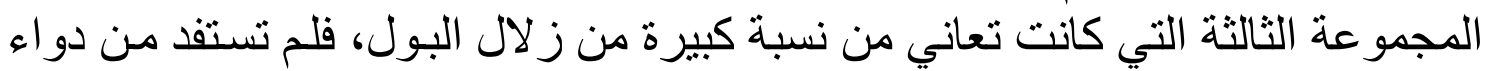

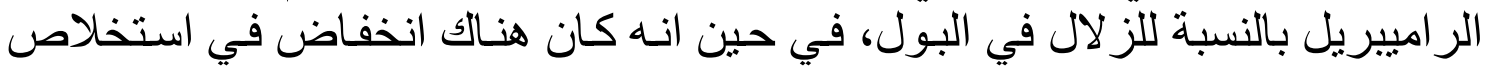

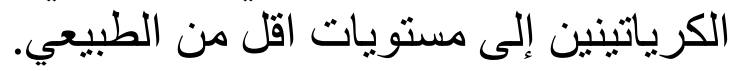

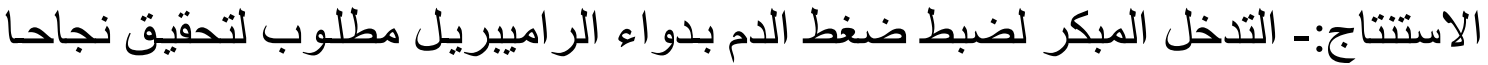

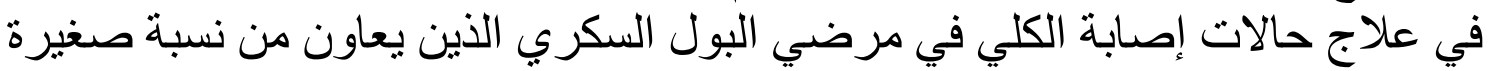

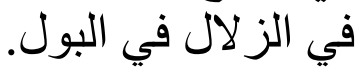

